\title{
PESQUISAS DE RECEPÇÃO E EDUCAÇÃO PARA OS MEIOS
}

\section{Tendências da pesquisa de recepção na América Latina representam contribuição efetiva para a formulação de propostas de estudos vinculados à Educação para os Meios}

A proposta que sustenta este trabalho é prioritariamente fruto de uma insatisfação com o rumo que vêm tomando as pesquisas de recepção no Brasil e na América Latina e de uma necessidade de fazer interagir, em novas bases, a pesquisa acadêmica crítica com os projetos de intervenção que estão no bojo dos movimentos sociais na região. A proposta diz respeito à criação de estratégias teórico-metodológicas capazes de vincular fortemente a pesquisa de recepção dos meios com a educação dos receptores.

\section{HISTÓRIA ANTERIOR}

Na América Latina, a pesquisa de recepção e os programas de Educação para os Meios historicamente se desenvolveram de forma independente, apesar de surgirem nos anos 80 como campos de estudo e de trabalho voltados para a cultura popular e de comungarem uma perspectiva crítica do sistema de comunicação de massa na sociedade.

A linha de Educação para os Meios se constituiu, em seus inícios, como uma linha de trabalho com os receptores, mais de de- núncia do que pedagógica, herdeira direta dos estudos críticos de comunicação da década de 70, majoritariamente desenvolvidos dentro da perspectiva teórica da Escola de Frankfurt ${ }^{1}$. Combinavam-se nesses estudos, de um lado, a rejeição global da indústria cultural por reproduzir a dominação através de mensagens ideológicas, persuasivas e conformistas e, por outro, uma concepção essencialista de cultura popular como conjunto de manifestações a ser preservado e protegido.

Essa visão teórica dicotômica levou o esforço pedagógico dos programas de Educação para os Meios a se concentrarem na desmistificação do sentido ideológico das mensagens pelos receptores, tentando vaciná-los contra os conteúdos veiculados. Os

A AUTORA
Maria Immacolata Vassallo de Lopes
Professora Doutora do Departamento de Comuni-
cações e Artes da ECA-USP e Presidente da IN-
TERCOM - Sociedade Brasileira de Estudos In-
terdisciplinares da Comunicação.

1. Termo que se refere à produção teórica do Instituto de Pesquisas Sociais da Universidade de Frankfurt, à qual se vinculavam Theodor Adorno, Max Horkheimer, Walter Benjamin (década de 30 e depois da II Guerra) e, mais tarde, Herbert Marcuse. Adorno e Horkheimer desenvolveram pesquisas empíricas com os modernos Meios de Comunicação de Massa, principalmente o rádio, que os levaram a formular os dois conceitos básicos de sua Teoria Crítica: o de Dialética do Esclarecimento (crítica à razão, ou ao racionalismo técnico-capitalista) e o de Indústria Cultural (crítica aos processos dos Meios de Comunicação de Massa que levam à cultura de massa, à homogeneização e à deterioração dos padrões culturais). (N.E.) 
meios de comunicação foram assumidos quase sempre como malefícios que deviam ser combatidos. Quase sempre a forma de combate era a construção de sistemas de informação alternativos e paralelos, levando ao prejuízo do "marginalismo", insistentemente assinalado por Martín-Barbero².

Ao longo da década de 80 a Educação para os Meios foi mudando o seu foco para experiências educativas com os receptores, seja a partir da família, escola, bairro, ou do grupo de pertencimento.

São experiências situadas no âmbito da educação formal e não-formal, desenvolvidas por ONGs e por instituições educacionais, em diversos países latino-americanos, com destaque para os programas do Brasil, Chile e Argentina ${ }^{3}$.

Por seu lado, a linha de pesquisa de recepção em comunicação é resultado de uma reação à crise dos paradigmas científicos ${ }^{4} \mathrm{e}$ que na América Latina se manifestou numa esquizofrenia teórico-prática, alimentada por uma concepção de "ciência dependente". Esta pode ser resumida como a que coloca sob suspeita o fazer teórico em países da periferia do capitalismo. Como diz Martín-Barbero: "A partir da direita, porque fazer teoria é um luxo reservado aos países ri- cos e o nosso é aplicar e consumir. A partir da esquerda porque os problemas 'reais', a brutalidade e a urgência das situações não dão direito nem tempo para o fazer teórico. $\mathrm{E}$, sem dúvida, a teoria é um dos espaçoschave da dependência. Seja através da crença na sua neutralidade-universalidade ou da tendência a viver das modas, buscando as ferramentas teóricas não a partir dos processos sociais que vivemos e sim de um compulsivo reflexo de estar em dia. Porém, a dependência não consiste em assumir teorias produzidas 'fora': dependente é a concepção mesma de ciência, de trabalho científico e de sua função na sociedade. Como em outros campos, também aqui o grave é que sejam exógenos não os produtos mas as próprias estruturas de produção"5.

Efeito de uma dupla matriz, epistemológica $^{6}$ e política, dos paradigmas, o empiricismo e o teoricismo são ideologias científicas que nutrem dicotomicamente as pesquisas de comunicação na América Latina, mesmo as de orientação crítica. Na tendência empiricista ${ }^{7}$, mostra-se claramente que não se rompeu com o modelo funcionalista ${ }^{8}$ de maneira efetiva, pois, em geral, pensamse os processos de comunicação de maneira vertical e unidirecional, com o que se torna difícil pensar a história e a dominação, uma vez que nesse modelo há dificuldade em se

2. MARTÍN-BARBERO, Jesús. Retos a la investigación de la comunicación en América Latina. in: FERNÁNDEZ, Fatima et al. Comunicación y Teoria Social. México:UNAM, 1984.

3. CANCLINI, Néstor G. El consumo sirve para pensar. Diálogos de la Comunicación. n.33, Lima: CENECA; Chile: Educación para la Comunicación, 1992.

4. Simplificando, pode-se pensar este termo como a crise dos modelos científico-mecanicistas. Tal discussão ganhou força com a crise do Leste Europeu, a fragmentação da URSS e o avanço do neoliberalismo. Propõe-se, como alternativa, uma concepção científica plural, multidisciplinar, globalizante. Ler sobre o assunto: KUHN, Thomas. A Estrutura das revoluções científicas. 3.ed., São Paulo: Perspectiva, 1990; e GRECO, Milton. A crise dos paradigmas, rigor científico e novos desafíos. in: . MEDINA, Cremilda. Saber plural: novo pacto da ciência - 3. São Paulo: ECA/CJE/CNPq. 1994, p. 17-30. (N.E.)

5. MARTÍN-BARBERO. Retos de la investigación....p. 50-51.

6. Crítica dos princípios, hipóteses e resultados de uma dada ciência. Referente à Teoria do Conhecimento.(N.E.)

7. Reconhece a experiência como única fonte válida de conhecimento. Comparado ao positivismo, designa, principalmente, o método, enquanto o positivismo designa a doutrina a que esse método conduz.(N.E.)

8. Paradigma científico de tradição positivista (Augusto Comte). Centra seus estudos nas funções que pessoas e instituições exercem na sociedade. Não trabalha com o conceito de classes sociais. Na Comunicação o funcionalismo tem como ponto de partida a contribuição de Talcott Parsons às Ciências Sociais. Os primeiros estudos de linha funcionalista na Comunicação são dos anos 30, nos Estados Unidos, através dos estudos da pesquisa de opinião de Lazarsfeld.(N.E.) 
tratar a contradição e o conflito. Na tendência teoricista, a pesquisa é confundida com especulação e a falta de trabalho empírico traduz-se num escapismo político, ou seja, faz-se pesquisa para escapar da "prática", para fugir da intervenção. Também aqui se nota o discurso generalizante, vazio e "fora de lugar", cuja marca é a abundância de reprodução e a falta de produção de teoria enraizada nas problemáticas específicas vividas pelos países do continente.

\section{PERSPECTIVA DA RECEPÇÃO: MEDIAÇÕES E COTIDIANO}

A partir dos anos 80, a pesquisa de recepção vem sendo trabalhada na América Latina como uma perspectiva teóricometodológica renovadora e original. Esta linha de pesquisa procura superar as limitações epistemológicas de modelos como os da pesquisa dos efeitos, pesquisa de audiências, pesquisa de usos e gratificações, estudos de crítica literária e estudos culturais.

A problemática da recepção, nesta orientação, busca uma (re)formulação teórico-metodológica ${ }^{9}$, que propõe organizar as tentativas interdisciplinares e de multi-métodos $^{10}$ numa malha teórica compreensiva, respondendo às demandas de complexidade e de crítica, tendo em vista a atual conjuntura da pesquisa internacional nesta área de conhecimento.
São fundamentais, nessa perspectiva, as contribuições teóricas latino-americanas. Elas consolidaram a linha teórica das mediações e das hibridizações, que propõe estudar a recepção como "um contexto complexo e contraditório, multidimensional, em que as pessoas vivem sua cotidianidade. Ao mesmo tempo em que vivem essa cotidianidade, os indivíduos se inscrevem em relações de poder estruturadas e históricas, as quais extrapolam as suas práticas" 11 .

No caso do Brasil, a pesquisa de recepção ainda necessita desenvolver uma experimentação metodológica de multi-métodos através de projetos integrados multidisciplinares que procurem combinar os avanços teóricos com as construções empírico-descritivas, e que realizem uma interpretação crítica, cultural e política dos processos de recepção da comunicação, a fim de que possam firmar uma ótica teórica compreensiva.

Investigar a recepção exige pensar tanto o espaço da produção como o tempo do consumo, ambos articulados pela cotidianidade (usos/consumo/práticas) e pela especificidade dos dispositivos tecnológicos e discursivos (gêneros) da comunicação de massa.

A abordagem teórico-metodológica da recepção apóia-se basicamente nas perspectivas das mediações ${ }^{12} \mathrm{e}$ do cotidiano.

9. LOPES, Maria Immacolata V. Estratégias metodológicas da pesquisa de recepção. INTERCOM - Revista Brasileira de Comunicação, Vol. XVI, 2, São Paulo, 1993.

10. LOPES, Maria Immacolata V. Pesquisas em comunicação. Formulação de um Modelo Metodológico. São Paulo: Loyola, 1990.

11. LOPES, Maria Immacolata V. Estratégias metodológicas da pesquisa de recepção. Idem, p.85.

12. De modo simplificado, podemos dizer que as mediações são os filtros por que passam quaisquer tipos de comunicação. Exemplificando: entre o fato ocorrido e o fato relatado há a mediação (os filtros) de quem faz o relato, que o faz a partir de seu ponto de vista, de sua cultura, de seus interesses. O processo de produção de uma mensagem jornalística é repleto de mediações desde o repórter até o receptor da notícia, o qual também procede à seleção e à compreensão a partir de um conjunto de fatores que operam em sua vida e em seu cotidiano. (N.E.) 
A mediação no processo de recepção deve ser entendida como processo estruturante que configura e reconfigura tanto $\mathrm{a}$ interação dos membros da audiência com os Meios, quanto a criação por parte deles do sentido dessa interação. A fim de torná-la metodologicamente manejável podemos resumir o seu sentido como se segue:

1. A relação dos receptores com os meios de comunicação é, necessariamente, mediatizada. Essa relação nunca é direta e unilateral como costuma ser abordada, mas é uma relação multilateral e multidimensional $\mathrm{e}$ realiza-se através de diversas mediações. Segundo Orozco ${ }^{13}$, elas são cognitivas, situacionais, institucionais, estruturais e videotecnológicas.

2. A recepção é um processo e não um momento, isto é, ela antecede o ato de usar um Meio e prossegue a ele. Assim, o sentido primeiro apropriado pelo receptor é por este levado a outros "cenários" em que costumeiramente atua (grupos de participação). Imagina-se então que uma mensagem de telenovela, por exemplo, deva ser reapropriada várias vezes e que, portanto, o processo de circulação de uma telenovela deve ser incorporado ao efeito de sentido que ela produz.

3. O significado de um Meio é "negociado" pelos receptores. Assume-se, então, que não há garantia de que os significados propostos por uma telenovela sejam apropriados da mesma maneira pelos receptores. Pode-se afirmar que os sentidos e os significados últimos de uma mensagem são produto de diversas mediações (étnicas, de classe, de sexo, institucionais etc.). Por um lado, isto significa que o processo de comunicação não se conclui com a sua trasmissão, senão que propriamente aí se inicia. Por outro lado, isso não implica a ausência de uma intencionalidade global, política e econômica concreta, que se inscreve no discurso social hegemônico. É precisamente esta intencionalidade que faz com que a realidade signifique "algo" e impede que qualquer significado seja transparente.

Outro aspecto que merece atenção nas pesquisas de recepção é o conceito de cotidiano. Como o conceito de mediação, seu desenvolvimento teórico está ligado à (re)discussão mais geral sobre os meios de comunicação de massa, tradicionalmente vistos a partir das idéias de alienação, manipulação, dependência ou colonialismo cultural. Começa-se, assim, a nuançar um pouco mais a análise, tentando perceber os diferentes graus de dependência ou a interdependência entre os sistemas de comunicação, além dos mecanismos de sedução e cumplicidade que unem produtores e receptores. Esta perspectiva busca então encontrar mediações e não um sistema impositivo de mão única, onde só existe lugar para dominantes e dominados.

Desta forma, o cotidiano seria uma dimensão a ser apreendida por instrumentos finos de pesquisa e análise, capazes de mostrar como as práticas cotidianas aparecem ligadas à recepção da televisão, por exemplo, conferindo-lhes novos sentidos ou influem na própria maneira a partir da qual estes são lidos, isto é, entendidos e apreendidos. Os diferentes modos de ler estão muito ligados às tradições, preocupações e expectativas da vida prática, incorporando-se, muitas vezes, a ela nas discussões familiares, alterando valores e comportamentos. 
Em termos teóricos isso significa uma aproximação com a Antropologia, área de conhecimento em que a cultura é pensada como modo de vida. Seguindo a tradição aberta por Michel de Certeau ${ }^{14}$, cresce a investigação teórica sobre a invenção do cotidiano.

As pesquisas de recepção, espécie de etnografia das audiências, revelam, cada vez mais nitidamente, que nem tudo está dado quando se analisa a produção, e que os usos modificam a cultura. Portanto, que o consumo deve ser considerado como um conjunto de práticas que produz sentido e não apenas assimila a cultura hegemônica ${ }^{15}$.

\section{RECEPÇÃO E EDUCAÇÃO PARA OS MEIOS}

Sem pretender propor integração completa entre ambos os campos de estudo e trabalho, parece-nos, entretanto, imprescindível explicitar algumas condições concretas que permitiriam vincular os esforços das pesquisas de recepção com um trabalho pedagógico com as audiências. Referimo-nos a:

\section{Pesquisas de recepção que produzem} novos conhecimentos sobre os processos de recepção, como por exemplo o Projeto de Recepção de Telenovela que se desenvolve no Departamento de Comunicações e Artes da ECA e que é parte de um Proje-

\section{Para Cer-} teau, a cultura hegemônica movese por meio de estratégias, através das quais pretende incorporar seus destinatários; estes, por seu lado, desenvolvem táticas, como respostas ao que lhes é proposto.

Sobretudo no que diz respeito às manifestações dos grupos, à vida cotidiana e às redes de lazer é possível afirmar
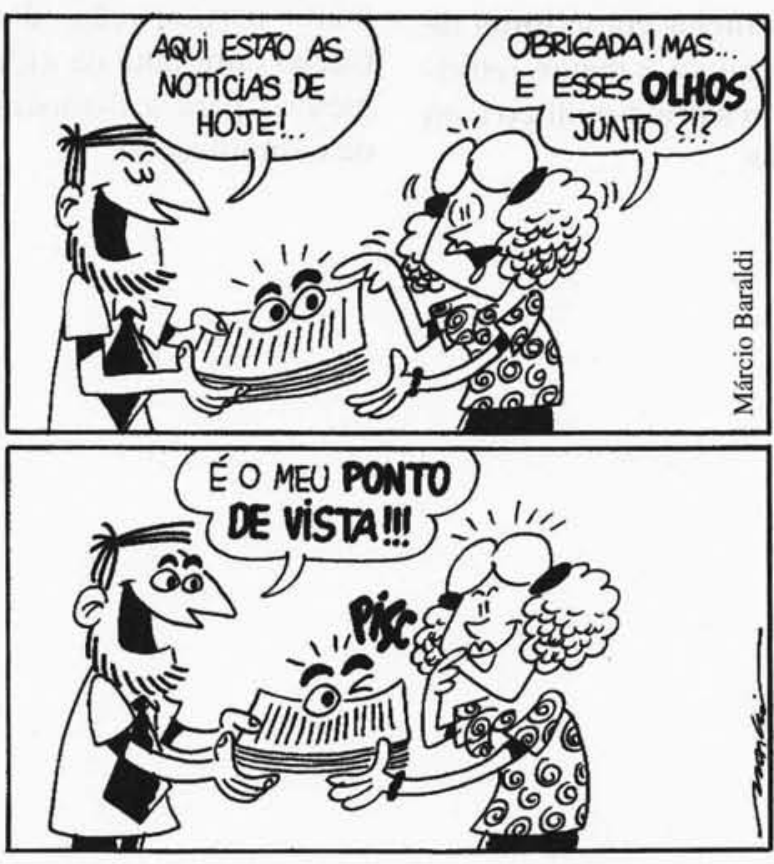

que as utilizações da cultura transbordam os sentidos, extrapolam a lógica da produção, criando formas não previstas pela indústria cultural. to maior denominado: Ficção e Realidade: a telenovela no Brasil; o Brasil na telenovela.

O conhecimento das mediações deve permitir fazer propostas pedagógicas muito mais refinadas para rearticular as mediações da audiência. Isto quer dizer que esse conhecimento é suscetível de ser explorado de maneira produtiva, isto é, de forma a ser aplicado nos trabalhos de Educação para os Meios e, principalmente, haver sobre eles intervenção dos próprios receptores. 
2. A Educação para os Meios como rearticulação pedagógica das mediações implica uma pesquisa sistemática destas e de seus principais componentes nos processos de recepção. Supõe uma espécie de pesquisa participante de recepção. Assim, a função principal da pesquisa de recepção não seria somente informar, retroalimentar e avaliar a Educação para os Meios, mas possibilitar processos de indagação e conhecimento coletivos das mediações e seus padrões de articulação entre diferentes segmentos de audiência. Podemos citar, como exemplo, o Projeto de Pesquisa que se desenvolve no Departamento de Comunicações e Artes da ECA, denominado a Recepção da Imprensa Sindical.

3. Educação para os meios como linha de trabalho mais investigativa e menos retórica, fruto de um vínculo teórico-político com a pesquisa de recepção.
Hoje, com os avanços das pesquisas de recepção orientadas por novas premissas, o processo de recepção é visto para além da relação do sujeito com os Meios. Ele é captado na trama de sentidos tecida pelas mediações que operam no cotidiano das pessoas.

Por isso, diante dos desafios do neoliberalismo ambiente, torna-se imprescindível que essa perspectiva comunicacional seja integrada à Educação para os Meios a fim de dar um impulso maior e mais fundamentado em seus programas pedagógicos. Ganham assim todos, comunicadores e educadores, com a possibilidade de maior participação das pessoas na construção cotidiana da cidadania e nos movimentos para a democratização dos meios de comunicação. 